\title{
血液透析前後における血清オプソニン化活性の検討
}

\author{
小林大樹山谷信菅原和夫 \\ 弘前大学衛生学講座
}

key words：オプソニン化活性, 慢性腎不全, 血液透析, chemiluminescence

〈要旨〉

生体防御機構には細胞性免疫, 液性免疫などさまざまな因子が関与しているが, 液性免疫である血清オプソニン 化活性は，透析患者では健常人に較べ低下していると報告されている，乥こで血液透析が血清オプソニン化活性に 与える影響について検討した。原疾患が慢性系球体腎炎の患者 20 名について透析前後の血清オプソニン化活性を好 中球を用いた chemiluminescence 法で測定, また透析前血清中の分子量 5,000 以下分画および血清濃度変化がオプ ソニン化活性に与える影響等について検討し，以下の結果を得た。1 . 透析前血清に較べ透析後血清でオプソニン 化活性が上昇していた，2．免疫グロブリン，補体は透析前後における血清オプソニン化活性に明らかな影響は与 えていないことが示唆された。3．透析前血清の分子量 5,000 以下分画中にはオプソニン化活性を低下させる因子 が存在することが示唆された．4．血清希勫によるオプソニン化活性の低下が示唆された．これらは, 透析患者の 易感染性の一因と考えられた。

\section{Pre and post hemodialytic opsonic activity}

Hiroki Kobayashi, Makoto Yamaya, Kazuo Sugawara

Department of Hygiene, Hirosaki University School of Medicine

Patients undergoing chronic hemodialysis are vulnerable to infection. Humoral and phagocytic cell components of the host immune system act against invading microorganisms. It has been reported that serum opsonic activity, an aspect of the humoral immune system, is lower than normal in patients undergoing chronic hemodialysis. In order to elucidate pre and post hemodialytic changes in opsonic activity, we studied 20 patients undergoing hemodialysis for chronic glomerulonephritis at Oyokyo Kidney Research Institute Hirosaki Hospital by chemiluminescence using neutrophils. We also studied factors affecting serum opsonic activity.

The following results were obtained; 1 . Serum opsonic activity before hemodialysis was lower than that after hemodialysis. 2. The factors interfering with serum opsonic activity had molecular weights $<5,000$ daltons in pre-HD serum. 3. Serum dilution interferes with serum opsonic activity. These factors contribute to the vulnerability of patients undergoing hemodialysis to infection.

\section{緒言}

慢性腎不全による血液透析患者は易感染性であ ることはよく知られており ${ }^{1,2)}$, 透析患者の免疫に 関する報告も数多く行われている ${ }^{3,4)}$.

生体防御機構には非特異免疫と過去に侵入した 異物や微生物に対応している特異免疫がある. 非
特異免疫を担うものの一つに好中球があり，感染 症防止に重要な役割を果たしている。好中球の異 物および微生物の排除には, 好中球自体の貪食, 殺菌能と好中球を異物侵入場所へ遊走させる走化 性因子，好中球の異物への接着を助けるオプソニ ン化因子などが重要となる。このうち血清オプソ

小林 大樹 弘前大学衛生学講座 $\quad$ 于 036 弘前市在府町 5 (0172-33-5111)

〔受付: 平成 6 年 9 月 29 日，受理：平成 7 年 2 月 3 日〕 
ニン化活性については, Lucchi $5^{5)}$ が健常人に較 べ透析患者で低下していると報告しているが，こ の原因や機序，血液透析によるオプソニン化活性 への直接的影響についても明らかにされていな い.

好中球殺菌能の測定方法として, chemiluminescence 法 (CL) が注目されている6,7). 好中球 は異物を貪食, 殺菌する際, 活性酸素種を産生す るが, CL 法はこの活性酸素種に起因する微弱発 光を測定するものであり ${ }^{8,9)}, \mathrm{CL}$ 法の応用により 血清オプソニン化活性の測定も行われ ${ }^{10)}$, その再 現性は良好とされている。そこで, 本研究は CL 法 を用いて透析前後における血清オプソニン化活性 の測定を行い，血液透析による影響とその原因に ついて検討し, 透析患者の易感染性の原因究明の 一助となる興味ある知見を得たので報告する。

\section{対象}

\section{1. 血液透析施行患者}

鷹揚郷腎研究所弘前病院で 1992 年 9 月現在, 血 液透析を行っている慢性腎不全患者のうち, 原疾 患が慢性系球体腎炎である 20 名（男性 10 名, 女 性 10 名, 30 66 歳, 平均 57.9 歳, 透析期間 9 か 月〜 5 年 2 か月, 平均 2 年 8 か月) を対象とした. 血液透析に使用する透析膜は, hemophan 膜 (メ ラネオクリスタル S : 泉工医科工業社)を用いた。

透析患者からの採血は透析開始直前および透析 終了時に行い，採血後 30 分間室温に放置し，500 G で10分間遠心して血清を分離，測定までー80 ${ }^{\circ} \mathrm{C}$ で保存した。透析開始直前の採血は, 左前腕の 内シャント血管より行い, 透析終了時には透析回 路の脱血側より行った. 測定の際には, $37^{\circ} \mathrm{C}$ 恒 温槽で速やかに解凍しこれを用いた。また，一部 を血液生化学検查に用い C $3, \mathrm{C} 4, \operatorname{IgG}, \operatorname{IgM}, \operatorname{IgA}$ 等を測定した。

\section{2 . 健常人}

健常人血清は年歯 26〜 40 歳（平均 30.7 歳）の 男性 8 名の肘正中静脈より採血したものを, 前述 の通り処理し血清を得た。また, 血液生化学検査 において異常值を示さなかった健康成人 120 名の 血清を分離しプール血清を作成，これを基準血清 とした. 健常人血清おょび基準血清も患者血清と
同様 $-80^{\circ} \mathrm{C}$ で保存し, 測定の際には, $37^{\circ} \mathrm{C}$ 恒温 槽で速やかに解凍して用いた。

好中球は, 28 歳の健常男性一人から分離しこれ を用いた。

\section{方法}

\section{1. 好中球分離法}

28 歳健常男性の肘正中静脈より採血した全血 を用いて，熊江ら ${ }^{11,12)}$ の報告に準じて比重勾配法 で好中球の分離を行った。分離後 Hanks' balanced salt solution (HBSS) で洗浄，さらに低張 食塩水による溶血操作を加えて残存赤血球を除去 し，好中球分画を得た。得られた試料を自動血球 計数装置 Sysmex F-3000（東亜医用電子社）を用 いて, 好中球数 $3.0 \times 10^{6} / \mathrm{m} l$ になるように HBSS で希釈調整し, 測定まで $4{ }^{\circ} \mathrm{Cで}$ 保存した。

2. 患者血清による被貪食粒子のオプソニン化

1) オプソニン化 zymosan の作製法

zymosan A（Sigma 社）を $1 \mathrm{mg} / \mathrm{m} l$ の濃度で HBSS に浮遊させ，この懸濁液 $400 \mu l$ に透析前 後血清または基準血清をそれぞれ $60 \mu l$ 加えて $37^{\circ} \mathrm{C}$ で 30 分間インキュベートした後， $500 \mathrm{G} て ゙$ 10 分間遠心した. 沈渣を HBSS にて 2 回洗浄し, 得られたオプソニン化 zymosan を用いて透析前 後におけるオプソニン化活性の測定を行った。

2 ) オプソニン化 E. coli の作製法

スキムミルク培地にー $80^{\circ} \mathrm{C}$ で保存した E. coli $(014 ； \mathrm{~K} 7 ： \mathrm{H}-\mathrm{SU} 4411 / 41)$ を解凍し, 普通寒天培 地にて 24 時間培養した後, 菌体を集め生理食塩水 で 2 回洗浄した。得られた菌体を $1 \times 10^{9} \mathrm{cfu} / \mathrm{m} l$ となるように HBSS で調整し,この浮遊液 $400 \mu l$ に被検血清 $60 \mu l$ を加えて $37^{\circ} \mathrm{C} て ゙ 30$ 分間イン キュベートした後， $1,600 \mathrm{G}$ で 30 分間遠心分離し た. 沈渣を HBSSで 2 回洗浄し, 得られたオプソ ニン化 E. coli を用いて透析前後におけるオプソ ニン化活性の測定を行った。

\section{3 ）オプソニン化活性の評価法}

好中球機能による差を補正するため, 対象とし て用いた基準血清の值を 100 として, 透析前後血 清の比率を求めその值を比較した。

3. 各検体に対寸る好中球 CL 測定方法 好中球 CL の測定は, Lumiphotometer TD- 
4000 (Labo Science 社) にコンピュータ（NEC PC9801 Vm）を接続して, 熊江ら ${ }^{11,12)}$ の報告した 多検体同時測定法に準じて行った．前述のオプソ ニン化した試料に，増感剈として $0.5 \mathrm{mM} ル ミ$ ノール (Sigma 社) または $0.8 \mathrm{mM}$ ルシゲニン （Sigma 社）を $100 \mu l$ 加え, 次に好中球浮遊液を $100 \mu l$ 加え測定を開始した.

測定值の処理は, 計測值の中で発光量が最大と なった点を中心に前後に 2 点, 計 5 点を取り, 最 小自乗法の二次曲線を用いて算出した。最大点の $\mathrm{X}$ 軸（min）と Y 軸（mV）の值をそれぞれ最大発 光時間 (peak time; PT), 最大発光量 (peak height；PH）として評価に用いた。

4. 血清オプソニン化活性に影響を及ぼす因子 の検討

\section{1 ）血清中の低分子量物質の影響}

患者 10 名と健常人 8 名について検討を行った。 ウルトラフリーCL ュニット（UFC4LCC25； Millipore 社）を用いて透析前患者血清および健 常人血清を $4{ }^{\circ} \mathrm{C}$ で $2,000 \mathrm{G}, 40$ 分間遠心分離し, 分 子量 5,000 以下の分画 $(5,000$ 以下分画) と残りの 血清（残余分画）を得た。これらの分画および無

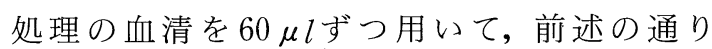
zymosan をオプソニン化し影響を調べた.また， 無処置の血清 $60 \mu l$ に,000 以下分画と HBSS をそれぞれ $40 \mu l$ 加え $100 \mu l$ とし，これを用い て zymosan をオプソニン化し, 5,000 以下分画の オプソニン化活性への影響を調べた。

\section{2 ）血清希釈による影響}

患者 6 名の透析前後血清について検討を行つ た。血清希釈による影響を調べるためにオプソニ ン化時の血清量を $40,60,80,100,120,140 \mu l$ と変 え,これらにHBSS を加えて総量 $140 \mu l$ とした。 これらを用いて前述の通り $400 \mu l$ の zymosan 懸 濁液をオプソニン化して測定を行った。

5 . 好中球走化性因子測定方法

患者 9 名について検討を行ったが，各測定毎に 対象として基準血清の測定も同時に行った。 zymosan A (Sigma 社) $1 \mathrm{mg} / \mathrm{m} l$ の濃度で HBSS に浮遊させ，この懸濁液 $400 \mu l$ に対して 基準血清あるいは被検血清である透析前後血清を
$60 \mu l$ それぞれ加え, $37^{\circ} \mathrm{C} て ゙ 30$ 分インキュベート した. その後 $500 \mathrm{G}$ で 10 分間遠心し, 上清を $56^{\circ} \mathrm{C}$ の恒温槽に 30 分間入れて非働化し,この zymosan 処理血清を遊走因子として用いた。 Osanai ら ${ }^{13)}$ の報告に準じて 48 穴ミクロケモタキ シスチャンバー (Neuro Probe 社)を用いて行っ た。ボトムプレート下室にこの遊走因子 $26 \mu l$ を 注入，その上に polycarbonate filter を装着, さ らに前述の方法で単離した好中球を細胞数 $2.0 \times$ $10^{5} / \mathrm{m} l$ になるように HBSS で希釈調整してトッ ププレート上室に $50 \mu l$ 注入した後, $37^{\circ} \mathrm{Cで} 20$ 分 間インキュベートした。インキュベート後 filter 下面に遊走した細胞をメタノール固定してギムザ 感染を行った. 染色した filterを 400 倍で検鏡し, 5 視野の細胞数を数え平均值を求めた。測定に用 いた好中球の機能は各測定間で必ずしも一定では ないため, 評価は基準血清に対する比で行った。

\section{6 . 統計的検定方法}

得られた測定值は対応のある $t$ 検定を用いて統 計的検定を行い，危険率 $5 \%$ 以下を有意とした。

\section{結果}

1. 透析前後血清によるオプソニン化活性の比 較

1）zymosan を刺激物として用いた場合

結果を図 1 に示した。増感剈としてルミノール および，ルシゲニンのいずれを用いた場合でも透 析後で PH は有意 $(\mathrm{p}<0.01)$ に上昇し, PT は 有意 $(\mathrm{p}<0.01)$ に短縮していた。 また，透析前 後血清とも基準血清より $\mathrm{PH}$ は低下し, $\mathrm{PT}$ は延 長していた.

2 ）E. coli を刺激物として用いた場合

結果を図 1 に示した。増感剤はルミノールを用 いたが，透析後で $\mathrm{PH}$ は有意（ $\mathrm{p}<0.01 ）$ に上昇 し, PT は有意 $(\mathrm{p}<0.05)$ に短縮していた。

2 。免疫グロブリン，補体の影響

主なオプソニン化因子である $\mathrm{C} 3, \mathrm{C} 4, \mathrm{IgG}$, $\operatorname{IgM}, \operatorname{Ig} \mathrm{A}$ の変化率と $\mathrm{CL}$ 各種測定值の変化率間 には，いずれも相関は認められなかった。

3 . 血清の分子量 5,000 以下分画の影響 処理前血清に対する 5,000 以下分画の容量は, 透析前血清で平均 $11.9 \pm 0.7 \%$, 健常人血清で 


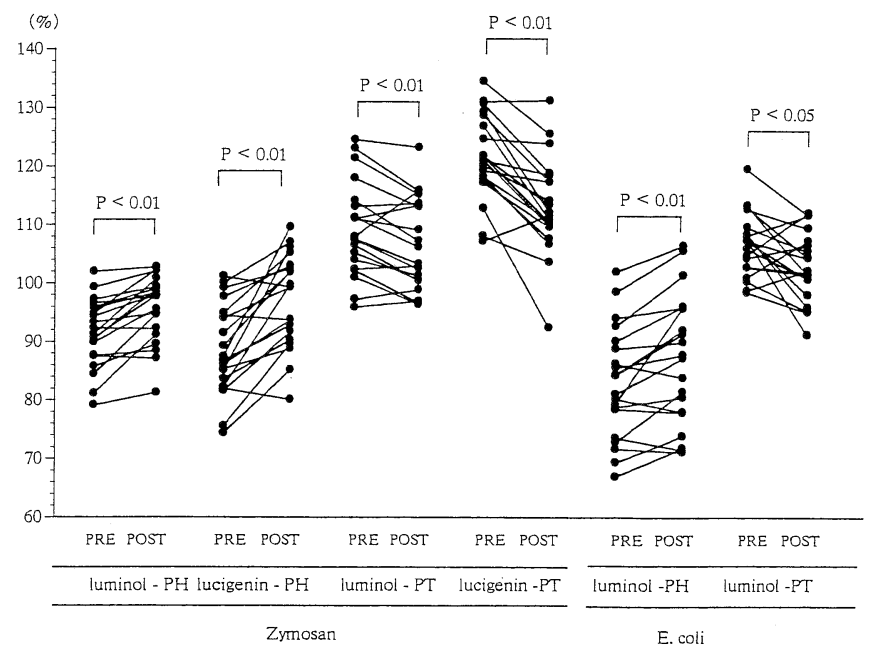

図 1 Serum opsonic activity pre and post hemodialysis

$11.3 \pm 0.4 \%$ であった。

透析前血清, 透析後血清, 透析前残余分画, 健 常人血清および健常人残余分画によるオプソニン 化 zymosan の CL の結果を図 2 に示した。 また, 透析前血清, 健常人血清に各人の 5,000 以下分画 および同量の HBSS を加え, CL を比較した結果 を図 3 に示した。

\section{1) $\mathrm{PH}$ に与える影響}

透析前血清（A）は透析後血清（B）および透 析前残余分画（C）に較べ有意（各々 $\mathrm{p}<0.01$, $\mathrm{p}<0.05 ） に$ 低下していたが，透析後血清（B） と透析前残余分画 (C) 間には有意差は認められ なかった。健常人血清 $(\mathrm{D})$ と健常人残余分画 $(E)$ には有意差は認められなかった（図 2 ).

5,000 以下分画でオプソニン化した場合の最大 実測值は透析前血清で平均 $8.5 \pm 4.2 \mathrm{mV}$, 健常人 血清で平均 $12.5 \pm 8.8 \mathrm{mV}$ といずれも $15 \mathrm{mV}$ 以下 である。これは非オプソニン化 zymosan と同程 度の発光であり, オプソニン化を行う物質は含ま れていないものと考えられた。

透析前血清に 5,000 以下分画を加えたもの (a) はHBSS を加えたもの（b) に較べ有意（p< 0.01）に低下していた. 健常人の分子量 5,000 以 下分画を加えたもの (c) と HBSS を加えたもの （d）には有意差は認められなかった（図 3 ).

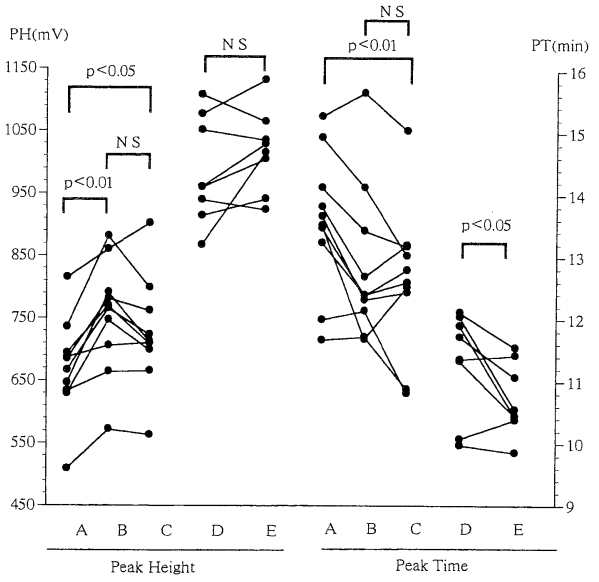

図 2 Effect of serum factors in the molecular weight range $<5,000$ daltons removing. A : Pre-HD serum B : Post-HD serum $\mathrm{C}:$ Pre-HD serum without factors in $\mathrm{MW}<5,000$ daltons $\mathrm{D}:$ Normal serum $\mathrm{E}:$ Normal serum without factors in $\mathrm{MW}<5,000$ daltons

\section{2 ）PT に与える影響}

透析前血清（A）は透析後血清（B）および透 析前残余分画 $(\mathrm{C})$ に較べ有意 $(\mathrm{p}<0.01)$ に延 長していたが, 透析後血清（B）と透析前残余分 画（C）間には有意差は認められなかった。健常 人血清（D）は健常人残余分画（E）と較べ有意 $(\mathrm{p}<0.05)$ に延長していた（図 2$)$.

透析前血清に 5,000 以下分画を加えたもの(a) 


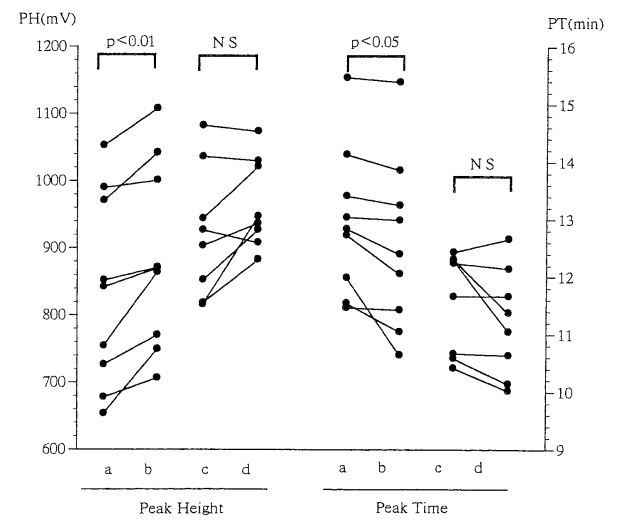

図 3 Effect of serum factors in the molecular weight range $<5,000$ daltons adding. a : Pre-HD $\operatorname{serum}(60 \mu l)+$ Pre-HD serum factors in $\mathrm{MW}<5,000$ daltons (40 $\mu l) \quad$ b : Pre-HD serum $(60 \mu l)+$ HBSS $(40 \mu l) \quad$ c : Normal serum $(60 \mu l)+$ Normal serum factors in $\mathrm{MW}<5,000$ daltons $(40 \mu l) \quad \mathrm{d}$ : Normal serum (60 $\mu l)+\operatorname{HBSS}(40 \mu l)$

はHBSS を加えたもの（b）に較べ有意（p< 0.05) に延長していた。健常人血清に分子量 5,000 以下分画を加えたもの（c）と HBSSを加えたも の（d）には有意差は認められなかった（図 3 ). 4. 血清希釈による影響

1) PH に与える影響

結果を図 4 の上段に示した。透析前血清では血 清量 $100 \mu l$ まで上昇し続けるが $120 \mu l$ 以上では 低下しており, 透析後血清では $100 \mu l$ まで上昇, $120 \mu l$ ではほぼ不変, $140 \mu$ lでは低下していた。 また各濃度において透析前血清に較べ透析後血清 がいずれも高く, PH の最高値の平均は透析前で $961.9 \pm 38.4(\mathrm{mV})$ ，透析後血清で $1,063.2 \pm 58.0$ $(\mathrm{mV})$ であり, 透析後で有意 $(\mathrm{p}<0.01)$ に高く なっていた。また，血液透析による除水の影響を 除くため, 透析前血清の測定值を総タンパク量 （TP）で補正したが，透析後血清への明らかな偏 位はみられなかった。

\section{2) PT に与える影響}

結果を図 4 の下段に示した.PT はオプソニン 化時の血清量が増加するにつれ短縮していた。し かし, 透析後血清では血清量 $120 \mu l$ と $140 \mu l$ 間
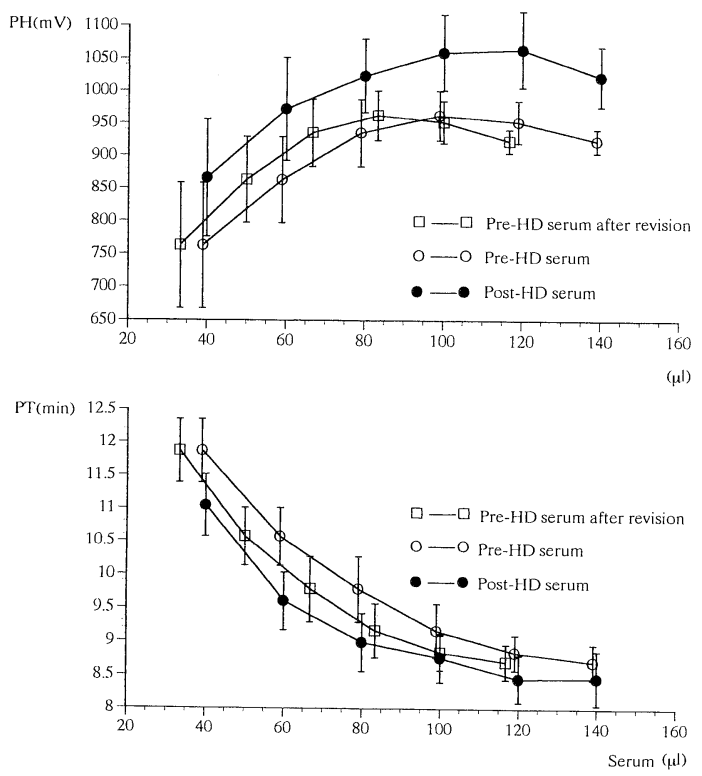

図 4 Effect of serum dilution. (Upper: peak height Lower: peak time)

で短縮傾向がみられなくなっていた。また各濃度 に扔いて透析前血清に較べ透析後血清で短縮して いるが, PT の最短時間の平均は透析前で $8.7 \pm$ 0.3 (min), 透析後で $8.5 \pm 0.4(\mathrm{~min})$ であり, 両者 に有意差を認めなかった。さらに, 血液透析によ る除水の影響を除くため, 透析前血清の測定值を TP で補正し，透析後血清濃度と等しくなるよう にすると，その值は透析後血清に近づいた。

5 。透析前後血清に対する好中球遊走能

表に結果を示した。透析前血清の平均は $100.1 \pm 16.8 \%$ ，透析後血清は $99.7 \pm 12.3 \%$ であ り, 両者間に有意差は認められなかった。このた め透析前後血清間には走化性物質の総力価には差 はみられないと考えられる。

\section{考察}

オプソニン化経路には, classical pathway と alternative pathway の 2 つの経路があり, zymosan は C3 を活性化して alternative pathway を起動させ ${ }^{14)}$, E. coli は IgG を介して classical pathway を起動させる。本研究におい て, 被貪食粒子として zymosan および E. coli を 用いた場合のいずれも透析後血清で $\mathrm{PH}$ が上昇, 
表 Chemotactic activity of neutrophils to pre and post hemodialysis serum

\begin{tabular}{c|cc|c|c|c}
\hline & $\begin{array}{c}\text { 透析前血清 } \\
(/ \mathrm{HPF})\end{array}$ & $\begin{array}{c}\text { 透析後血清 } \\
(/ \mathrm{HPF})\end{array}$ & $\begin{array}{c}\text { 基準血清 } \\
(/ \mathrm{HPF})\end{array}$ & $\begin{array}{c}\text { 前・比 } \\
(\%)\end{array}$ & $\begin{array}{c}\text { 後・比 } \\
(\%)\end{array}$ \\
\hline case 1 & 43.2 & 47.4 & 45.2 & 95.6 & 104.9 \\
case 2 & 50.8 & 47.4 & 49.6 & 102.4 & 95.6 \\
case 3 & 39.4 & 31.0 & 34.2 & 115.2 & 90.6 \\
case 4 & 28.2 & 36.8 & 36.4 & 77.5 & 101.1 \\
case 5 & 37.0 & 36.4 & 45.0 & 82.2 & 80.9 \\
case 6 & 31.8 & 37.6 & 41.6 & 76.4 & 90.4 \\
case 7 & 36.7 & 40.8 & 32.1 & 114.3 & 127.1 \\
case 8 & 57.0 & 50.2 & 49.2 & 115.9 & 102.0 \\
case 9 & 59.0 & 48.6 & 121.4 & 104.9 \\
\hline 平均土標準偏差 & \multicolumn{7}{|c|}{51.0} & $42.4 \pm 6.3$ & $100.1 \pm 16.8$ & $99.7 \pm 12.3$ \\
\hline
\end{tabular}

PT が短縮しており，オプソニン化活性は両経路 とも透析後血清で改善していることが示唆され た.

補体はオプソニン化に関与しており，血液透析 により活性化されることはよく知られている.C3, C5 が活性化する過程で産生される C3a と C $5 \mathrm{a}$ は 強力な走化性物質であるが'5), Jacobs ${ }^{16)}$ は血液 透析中 C3a, C5a は高值を示すが透析終了時には 透析前值にもどると述べている. 今回透析前後血 清を zymosan で刺激し好中球に対する走化性を 調べたが, 透析前後で有意な差は認められず C3, C5 の活性化には差がないと考えられた。またC3， $\mathrm{C} 4$ および免疫グロブリンと CL 各測定值には相 関が認められなかったことから, 透析前後のオプ ソニン化活性の変化は, 補体の活性化や免疫グロ ブリン等の影響によるものではなく, 透析膜の生 体適合性の違いによる差はないものと考えられ た。

血液透析前後では尿毒症物質の除去により血液 環境は大きく変化している. 今回血液透析に用い た hemophan 膜は, 溶質除去能に関して従来のセ ルロース膜と差がないことが報告されており ${ }^{17)}$, cut off point は分子量 $1 \times 10^{3} \sim 1 \times 10^{4}$ の範囲に あり,イヌリン(分子量約 5,000$)$ に対する篩係数 は 0.5 である.そこで透析前血清の分子量 5,000 以下分画を分離しオプソニン化活性に与える影響 を検討した。

まず PH について検討する。健常人血清と健常
人残余分画間には有意差が認められず，健常人で は 5,000 以下分画除去では, 明らかな影響はない と考えられる.しかし, 透析前血清からの 5,000 以 下分画除去で $\mathrm{PH}$ は有意に上昇し, さらに透析前 血清の 5,000 以下分画を添加したものは対象に較 べ有意に低下していたことから，透析前血清の 5,000 以下分画内に $\mathrm{PH}$ を低下させる因子の存在 が示唆された. 透析後血清と透析前残余血清間に 差がないこともこれと矛盾しない.

次にPTであるが, 健常人血清の 5,000 以下分 画を添加したものは対象と較べ有意差はないこと から健常人 5,000 以下分画は PT に影響を与え ないと考えられる. しかし, 健常人血清からの 5,000 以下分画除去で PT は有意に短縮してお り, 健常人では残余分画内因子の濃縮により $\mathrm{PT}$ は短縮するものと考えられた。 また, 透析前血清 からの 5,000 以下分画除去で PT は有意に短縮 し,さらに透析前 5,000 以下分画を添加したもの は対象に較べ有意に延長していたことから, 透析 前血清 5,000 以下分画内に PT を延長させる因 子の存在が示唆された.

現在, ガスクロマトグラフィーなどにより種久 の尿毒症物質が同定されているが, これら物質の オプソニン化活性への影響に関する報告はなく, オプソニン化活性を低下させる物質の特定は, 今 後の検討課題である.

透析施行患者は腎機能がほほ廃絶しているため 水分過剰状態にあり，これを透析による非生理的 
除水で是正している. そこで, 血清希釈による CL への影響を調べるため, オプソニン化時の血清濃 度を変え $\mathrm{CL}$ を測定した。 PH は透析前後血清と もある濃度まで上昇していたがその最大值には有 意差を認め,さらに透析前血清を TP で補正して も透析後血清に近似しないことより, 血清希釈以 外の因子がオプソニン化活性に影響を与えている ことが考えられた．PT では透析前後血清とも濃 度が上昇するにつれ短縮し, また透析前血清の TP による補正では透析後血清に近似しており， 血清希釈による影響を受けていることが考えられ た.さらに, 健常人血清と健常人残余分画におい て PT にのみ有意な差があったこともこれを支 持している.これらの機序としては血清希釈によ りオプソニン化量が減少し, 異物 (zymosan) へ の好中球の貪食が遅れるため PT が延長する。し かし, 一度貪食されると, 異物およびオプソニン 化物質に見合った活性酸素が放出されるため $\mathrm{PH}$ への明らかな影響がないと考えられる。

以上より, 透析前血清の分子量 5,000 以下分画 中には，PH を低下，PT を延長させる因子すな わちオプソニン化活性を低下させる因子が存在 し, また水分の過剰状態による血清希釈も PTを 延長させオプソニン化活性を低下させている。こ れらは好中球の食作用を低下させ, 透析患者の易 感染性の一因となっていると考えられた。

\section{結語}

血液透析前後における血清オプソニン化活性を CL 法を用いて測定し，血液透析による影響とそ の原因について検討した。

1. 透析後血清に較べ透析前血清では, zymosan および E. coli のいずれに対しても PH は減少し, PT は延長していることからオプソニ ン化活性が低下していると考えられ, 透析患者の 易感染性の一因になっていると考えられる.

2. 透析前に較べ透析後での血清オプソニン化 活性の改善は, 補体および免疫グロブリンによる ものではないと考えられた。

3.PT は血清希釈により延長しており, 透析 前血清のオプソニン化活性低下の一因と考えられ た。
4. 透析前血清の分子量 5,000 以下分画には $\mathrm{PH}$ を低下させ，PT を延長させる因子が存在す ることが示唆され, 透析前血清のオプソニン化活 性低下の一因と考えられた。

\section{文献}

1) Dobbelstein $H$ : Immune system inuremia. Nephron $17:$ 409-414, 1976

2) Keane WF, Shapiro FL, Raij L : Incidence and type of infection occurring in 445 chronic hemodialysis patients. Trans Am Soc Artif Internal Organs $23: 41-47,1977$

3）上田雄一郎：透析患者における食細胞の活性酸 素放出能の検討. 感染症学雑誌 $63: 997-1005$, 1989

4) Eckardt KU, Eckardt H, Asscher AW : Analysis of polymorphonuclear leukocyte respiratory burst activity in uremic patients using whole blood chemiluminescence. Nephron $43: 274-278,1986$

5) Lucchi L, Gianni C, Acerbi MA, Spattini A, Lusvarghi E: Oxidative metabolism of polymorphonuclear leukocytes and serum opsonic activity in chronic renal failure. Nephron $51:$ 44-50, 1989

6) Allen RC, Loose LD : Phagocytic activity of a luminol-dependent chemiluminescence in rabbit alveolar and peritoneal macrophages. Biochem Biophys Res Commun 69 : 245-252, 1978

7) Wilson ME, Trush MA, Dyke KV, Kyle JM, Mullett MD, Neal WA : Luminol-dependent chemiluminescence analysis of opsonophagocytic dysfunction. J Immunol Methods $23: 315-326,1978$

8) Allen RC, Stejernholm RL, Steele RH : Evidence for the generation of an electronic exitation state $(\mathrm{s})$ in human polymorphonuclear leukocytes and its participation in bactericidial activity. Biochem Biophys Res Commun $47: 679-684,1972$

9）佐倉伸夫, 小林陽之助, 臼井朋包：白血球殺菌 能試験一Chemiluminescence. 細胞性免疫機能 検査のすべて（月刊 Medical Technology 編）, 
p 29-34, 医歯薬出版，東京，1985

10) Easmon CSF, Cole PJ, Williams AJ, Hastings $\mathrm{M}$ : The measurement of opsonic and phagocytic function by luminol-dependent chemiluminescence. Immunology $41: 67-74$, 1980

11）熊江隆, 菅原和夫, 町田和彦, 島岡章： Luminol-dependent chemiluminescence を応 用した血清オプソニン活性の多検体同時測定 法. 日衛誌 $40 ： 876-884,1986$

12）熊江 隆, 菅原和夫：好中球 chemiluminescence の多検体同時測定法.日血会誌 50：949-957, 1978

13) Osanai T, Shiroto C, Mikami Y, Kudou E, Komatsu T, Suzuki K, Nakaji S, Kumae T, Sugawara K, Sasaki M : Measurement of Ga AlAs diode laser action on phagocytic activity of human neutrophils as a possibile therapeutic dosimetry determinant. Laser Therapy
$2: 123-133,1990$

14）谷内 昭：免疫グロブリンと補体, 医科免疫学, 菊地浩吉編, 第 2 版, p 105, 南江堂, 東京, 1984

15) Craddock PR, Fehr J, Dalmasso AP, Brigham KL, Jacob HS: Hemodialysis leukopenia. Pulmonary vascular leukosytasis resulting from complement activation by dialyzer cellophane membranes. J Clin Invest 59:879888, 1977

16) Jacobs AAJ, Ward RA, Wellhausen SR, McLeish KR : Polymorphonuclear leukocyte function during hemodialysis: Relationship to complement activation. Nephron $52: 119$ 124, 1989

17) Bosch T, Schmidt B, Samtleben W, Gurl $\mathrm{HJ}$ : Biocompatibility and clinical performance of a new modified cellulose membrane. Clin Nephrol 26 (Suppl) : 22-29, 1986 